\title{
Utvidet repertoar ved status epilepticus
}

\section{Prehospital behandling av kram- per kan godt omfatte midazolam gitt intramuskulært av hjelpeper- sonell. Det viser ny studie.}

Rask behandling av status epilepticus er viktig. Allerede når et krampeanfall har vart over fem minutter, oppfattes det som et begynnende status epilepticus, fordi det da foreligger en svikt i de mekanismene som normalt avslutter anfallet. Det opptrer dynamiske forandringer i GABA-reseptorer, og

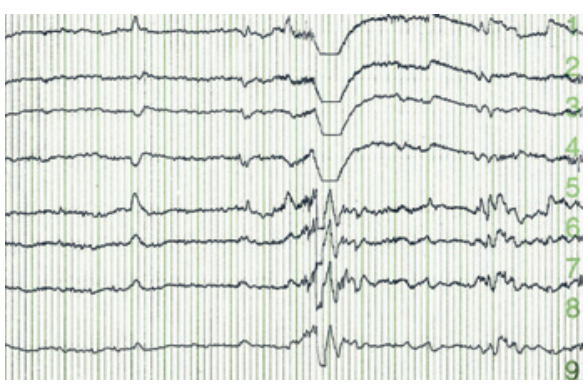

Foto Istockphoto benzodiazepiner kan etter hvert tape effekt. Intravenøs injeksjon med diazepam gitt raskest mulig har lenge vært standardbehandlingen ved status epilepticus.

Med tanke på bl.a. ambulansepersonell og annet helsepersonell som kommer til hjelp utenfor sykehus, er det gjennomført en randomisert studie av effekten av intramuskulær behandling (1). Behandlingsalternativene var $10 \mathrm{mg}$ midazolam intramuskulært/ placebo intravenøst eller placebo intramuskulært/4 mg lorazepam intravenøst.

Signifikant flere pasienter var anfallsfrie ved ankomst til sykehuset blant pasienter i gruppen som fikk intramuskulær behandling (73\% mot $63 \%$ ). Intramuskulær behandling kom heller ikke signifikant dårligere ut (noninferior) når det gjaldt anfallsresidiv, trakeal intubering eller tid før anfallet ga seg.

- Dette er en stor, randomisert og kontrollert undersøkelse av høy kvalitet som viser at prehospital behandling med midazolam intramuskulært er bedre enn lorazepam intravenøst, sier overlege Eylert Brodtkorb, Nevrologisk avdeling, St. Olavs hospital.

- Intramuskulær administrasjon går raskere, og legemidlenes farmakokinetiske egen- skaper spiller sannsynligvis en større rolle enn de farmakodynamiske. Det gjelder særlig penetrasjonen gjennom blod-hjerne-barrieren. I motsetning til diazepam markedsføres ikke lorazepam i Norge, men foretrekkes i USA pga. lavere redistribusjon til fettvev.

Prehospital anfallsbehandling med diazepam rektalløsning gitt av omsorgspersoner har i flere tiår vært brukt i Norge, men i mindre grad i USA. Midazolam løsning i munnslimhinnen brukes stadig mer. Effektiv dose kan gis i et lite volum, men ved status epilepticus kan det ofte renne ut før effekt oppnås. De fleste som utvikler status epilepticus, er ikke selv utstyrt med benzodiazepiner til akuttbehandling. Midazolam gitt intramuskulært av ambulansepersonell, kan være et enkelt og effektivt alternativ, sier Brodtkorb.

\section{Geir W. Jacobsen}

geir.jacobsen@ntnu.no

Tidsskriftet

\section{Litteratur}

1. Silbergleit R, Durkalski V, Lowenstein D et al. Intramuscular versus intravenous therapy for prehospital status epilepticus. N Engl J Med 2012; 366: $591-600$.

\section{Kapnografi ved behandling av akutt hjertestans?}

\author{
Kapnografi gir verdifull informasjon under hjerte-lunge-redning, \\ men utfallet påvirkes av flere forhold.
}

Kapnografi måler karbondioksid i utåndingsluft (end tidal carbon dioxide - $\mathrm{ETCO}_{2}$ ) og gjenspeiler produksjon, transport via blodbanen og utlufting via lungene. Teknikken er best kjent ved vurdering av ventilasjon av pasienter, men kan også brukes som et indirekte mål på pasientens sirkulasjon, forutsatt at $\mathrm{CO}_{2}$-produksjon og ventilasjon holdes konstant. Teknologien er tilgjengelig for feltbruk og integrert i flere defibrillatorer. Internasjonale retningslinjer anbefaler bruk av kapnografi under behandling av hjertestans.

I tillegg til å bekrefte korrekt tubeplassering er hensikten med kapnografi under resuscitering å sikre at pasienten får brystkompresjoner på en måte som gir best mulig sirkulasjon. I motsetning til ytre faktorer som kompresjonsdybde, frekvens osv. kan kapnografi gjenspeile hjertets minuttvolum.

Vi har nylig publisert resultatene fra en undersøkelse av 575 pasienter med hjertestans som i perioden 2004-09 ble behandlet av Statens luftambulanse, Bergen (1). Vi sammenholdt våre kapnografiregistreringer med kjernedata for den enkelte pasient (de såkalte Utstein-data), og kunne vise hvordan funnene varierte avhengig av hva som lå bak hjertestansen. Faktorer som kunne påvirke resultatene var bl.a. at publikum startet hjerte-lungeredning (HLR), årsaken til hjertestans, primærrytme og når i behandlingsforløpet målingene ble gjort. Disse begrenset nytten av måleverdiene med tanke på å forutsi om pasienten fikk tilbake spontan sirkulasjon. Faglige instanser som foretar avansert hjerte-lunge-redning anbefales å bruke kapnografi for å sikre pasientens sirkulasjon og for å oppdage egensirkulasjon hos pasienten i en tidlig fase.

\section{Bård E. Heradstveit}

baard.heradstveit@helse-bergen.no

Kirurgisk serviceklinikk/Akuttmedisinsk seksjon Haukeland universitetssykehus

\section{Litteratur}

1. Heradstveit BE, Sunde K, Sunde GA et al. Factors complicating interpretation of capnography during advanced life support in cardiac arrest - a clinical retrospective study in 575 patients. Resuscitation 2012; 83: 813-8.

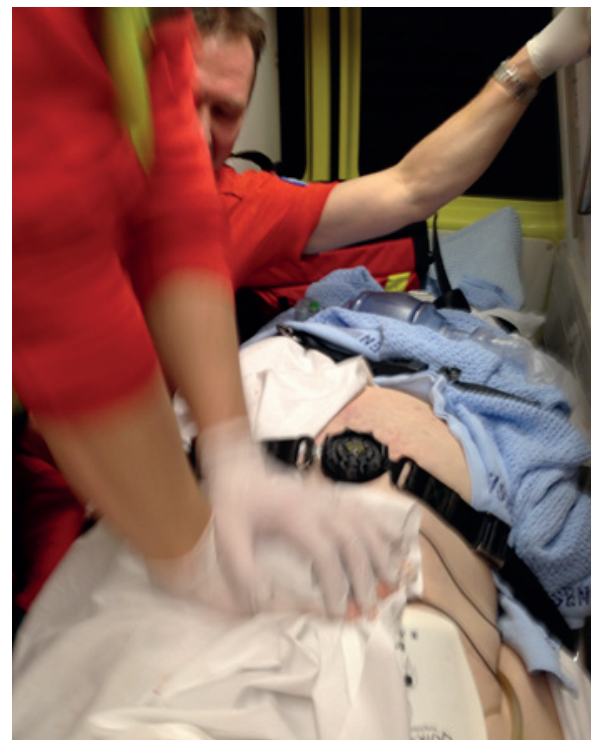

Foto Bård E. Heradstveit 